Research, part of a Special Feature on Networking the Environment: Social Network Analysis in Environmental Management and Local Ecological Knowledge Studies

\title{
Participation in protected areas: a social network case study in Catalonia, Spain
}

\author{
Laura Calvet-Mir $^{1,2}$, Sara Maestre-Andrés ${ }^{3}$, José Luis Molina $^{4}$ and Jeroen van den Bergh $^{3,5,6}$
}

\begin{abstract}
Local participation of stakeholders in governance of protected areas is considered to be important to natural resource management and biodiversity conservation. Social network analysis (SNA) is a useful tool for analysis because it allows the understanding of stakeholders' relationships, interactions, and influences through communication networks. We combine quantitative and qualitative data to undertake a SNA for the natural park of Sant Llorenç del Munt in Catalonia, Spain. This is aimed at (1) assessing the structure of the communication network; (2) comparing the informal communication network with the formal participatory bodies of the natural park; and (3) selecting participants for subsequent analyses of the adequate governance structure of the natural park. The results suggest that an informal network of communication, which is reasonably well represented in participatory bodies, exists. However, this communication network is not functioning perfectly because stakeholders experience a lack of trust in the governance bodies of the park, which they perceive to be ineffective. Our results show that SNA is an effective tool to support the creation of a broad representation of stakeholders in participatory processes.
\end{abstract}

Key Words: communication network; natural resource governance; resource management; social network analysis; stakeholder analysis.

\section{INTRODUCTION}

Local participation in governance of protected areas is considered to be important to natural resource management and biodiversity conservation (Dudley 2008, Borrini-Feyerabend et al. 2013). Participation has been defined by Wesselink et al. (2011) as any type of inclusion of nonstate actors, both members of the public or organized stakeholders, in any stage of governmental policy making. Several studies have emphasized the need for participation in governmental decisions (Fiorino 1990, Fischer 1993, Blackstock and Richards 2007, Reed 2008, Wesselink et al. 2011). Various reasons for these have been identified: participation assures more legitimate decisions, thus enhancing public credibility in governments; it reduces potential conflicts between different stakeholders; it increases the variety of information that contributes to better decisions; and it counters the power of incumbent interests by allowing all those affected by a decision to influence the associated decision process.

Before the 1980s, communities tended to be excluded from public decision making, or their participation was even regarded as counterproductive to natural resource management (Ruíz-Mallén et al. 2013). This approach was challenged by studies that stressed the inclusion of local people in natural resource governance (Hutton et al. 2005). The rights and need for local participation in decision making into protected areas was articulated at successive world congresses on national parks and protected areas, particularly the third in 1982 and the fourth in 1992 (McNeely 1992), as well as in the Convention on Biological Diversity (CBD 1992). Recently, active stakeholder participation has been recognized as a key factor of effective area protection in the Programme of Work on Protected Areas (PoWPA) of the CBD (Dudley 2008) and in the 2020 biodiversity strategy (European Union 2011).
Participatory initiatives for natural resource management nowadays include stakeholder analysis, that is, the process of identifying individuals or groups that are likely to affect or be affected by conservation efforts (Freeman 1984, Reed et al. 2009). This type of analysis has responded to the failure of many past conservation plans caused by paying insufficient attention to the interests and characteristics of stakeholders (Grimble and Wellard 1997). There is now increasing recognition and understanding of how stakeholders can or should influence natural resource management (Burroughs 1999, Prell et al. 2009). However, stakeholder analysis has two main limitations. First, stakeholders are usually identified and categorized through a subjective assessment of their relative power, influence, and legitimacy leading to a misrepresentation of stakeholders (Frooman 1999). Second, methods for stakeholder analysis often overlook the role communication networks can play in categorizing and understanding stakeholder relationships (Prell et al. 2009). Social network analysis is a tool that can help to overcome these shortcomings by providing insights into the social structure of stakeholders (Prell et al. 2008).

We studied the social network of communication with regard to the natural park of Sant Llorenç del Munt, a protected area situated in Catalonia, Spain. We based our research on previous studies suggesting that the exchange of knowledge and information is crucial for effective governance of natural resources (Bodin and Crona 2009) and that social network analysis may disclose the communication networks of stakeholders (Prell et al. 2011). Social networks are observable social structures (Bodin et al. 2006) made up of individuals or organizations tied by one or more specific types of interdependency, such as common interests or communication exchange. Social network analysis may demonstrate the existence and importance of social drivers supporting natural resource

\footnotetext{
${ }^{1}$ Internet Interdisciplinary Institute (IN3), Universitat Oberta de Catalunya, Barcelona, Spain, ${ }^{2}$ Institute of Environmental Science and Technology, Universitat Autònoma de Barcelona, Barcelona, Spain, ${ }^{3}$ Institute of Environmental Science and Technology, Universitat Autònoma de Barcelona, ${ }^{4}$ Department of Social and Cultural Anthropology, Universitat Autònoma de Barcelona, ${ }^{5}$ ICREA, Barcelona, Spain, ${ }^{6}$ Faculty of Economics and Business Administration and Institute for Environmental Studies, VU University Amsterdam
} 
management (Beilin et al. 2013), reveal structural characteristics of networks that articulate the patterns of connectivity between actors, and influence natural resource management outcomes (Bodin and Crona 2009).

We combined quantitative and qualitative data collection to undertake social network analysis, with the aim to map the local exchange network of information and examine to what extent this exchange of information is being reflected in formal participatory bodies. The concrete objectives of the research are: (1) to assess the structure of the communication network associated with the natural park; (2) to compare the informal communication network between stakeholders with the formal participatory bodies of the natural park, to see whether the latter represents the actual social network; and (3) to select participants for later analyses aimed at assessing the adequate governance structure of the natural park.

\section{METHODS}

We collected data on the natural park of Sant Llorenç del Munt, Catalonia (Fig. 1) between January and November 2013 and between April and September 2014. Data collection included nonparticipant observation, review of documents, semistructured interviews, and online/telephone surveys.

Fig. 1. Map of the study area.

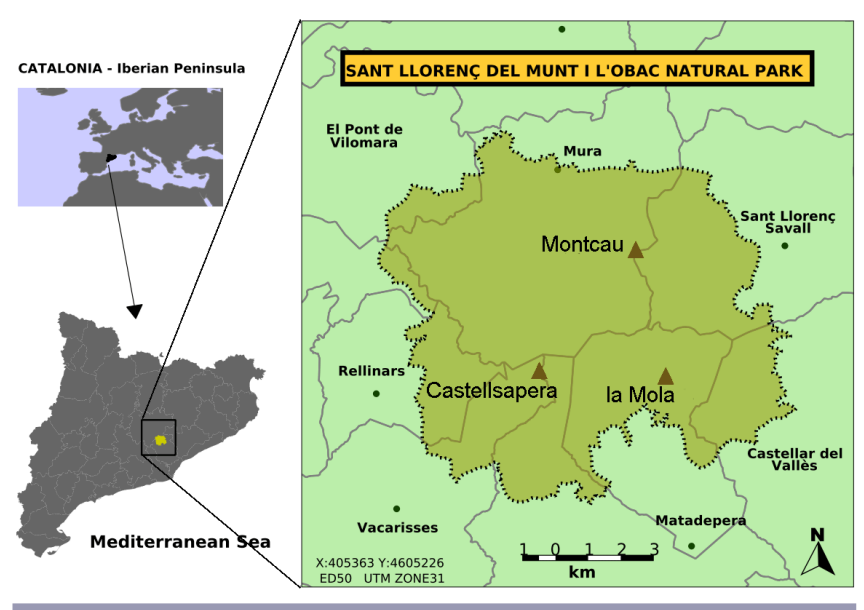

Description of the natural park

The natural park of Sant Llorenç del Munt is a protected area created in 1987 corresponding to category V, i.e., protected landscape, of the IUCN classification of protected areas. This category is created to protect the ecological, biological, cultural, and scenic value of these areas (IUCN 1994). The park is located in the northeast of Spain, within the Catalan precoastal mountains covering 13,694 hectares and comprising 12 municipalities. It is surrounded by large cities from the Barcelona Metropolitan Region, which contributes to a high frequency of visitors. It consists of a mixture of private $(59.20 \%)$ and public landownership (Diputació de Barcelona 2012). Traditional activities have nearly disappeared, e.g., exploitation of oak to produce charcoal, or have greatly diminished, e.g., agriculture, logging, and cattle grazing (Aguilar 2012). Currently, the service sector is the largest activity in the park, mainly because of its close relation with tourism. During the last decades, the main trends occurring in social-ecological terms are an expansion of urbanized areas, abandonment of traditional rural activities, growth of forest cover, and an increase in the risk of fires (Otero 2010).

The natural park of Sant Llorenç was initially protected in 1972 by the "Pla Especial d'Ordenació" (special land-use plan). However, the reason for the initial protection of the area under Franco's dictatorship (1939-1975) was legitimizing residential areas in the surroundings of the protected area while conserving higher areas difficult to be urbanized (Aguilar 2012). The social and ecological value of the area and the threat of quick urban spread stimulated the emergence of a conservationist movement at the end of the 1970s. This movement was mainly structured around hiking groups present in most villages and cities in the surroundings of the protected area and was highly influenced by the political and social context of the democratic transition period after the dictatorship (Aguilar 2012). This contributed to the area being assigned the official status of a natural park by the Catalan government in 1987.

The natural park is managed by the Diputació de Barcelona, a regional administration corresponding to the territorial area of the Barcelona Province. The governance of the natural park includes two participatory bodies: the coordinating council and the advisory committee. The coordinating council is the formal institution that guarantees the participation and collaboration in park management of the different public administrations with competencies in specific areas. It meets every six months and is composed of representatives of the Diputació de Barcelona, representatives from the council of each municipality that has part of its area inside the protected area, a representative of the Catalan Government (Generalitat de Catalunya), and a representative of the park's advisory committee. The Diputació de Barcelona proposes most of the actions and plans to be developed whereas the other public administrations have to validate these proposals, but are also allowed to propose initiatives. The advisory committee is an informative public meeting of stakeholders and park managers held every six months. Its main objectives are twofold: (1) inform stakeholders about the policies and actions implemented or planned to be executed; and (2) collect the comments of stakeholders on the issues presented, even though these comments are not binding. The advisory committee was established in 1986 to "guarantee stakeholder participation, understanding this participation as a non-professionalized and unpaid voluntary action, and aimed at facilitating the suitability of decision-making to social demands" (Diputació de Barcelona 1997:31). It is composed of representatives of the Diputació de Barcelona, the coordinating council, and the various social, economic, scientific, cultural, and conservationist organizations with a stake in the management of the natural park. Our research focuses on analyzing the advisory committee as a formal participatory body, given that every single stakeholder can join, and compare it with the existing informal network of communication among stakeholders.

\section{Data collection}

\section{Nonparticipant observation}

We used nonparticipant observation techniques to establish contact with the community, local culture, and local social 
organization in a nonactive way (Bessette 2004). We undertook several trips from January to June 2013 to visit the 12 municipalities that have part of their area within the natural park, and we had informal talks with individuals or groups to know the relationship of each municipality with the natural park. In addition, we stayed two weeks in July and August 2013 in a farmhouse inside the park. This stay gave us knowledge about the situation of people living inside the protected area and their perceived role of participation in natural park governance. We also participated in a meeting of the advisory committee to observe how this participatory body works and how stakeholders interact.

\section{Review of documents}

We reviewed all the available documents about attendance to meetings of the advisory committee from 2008 to 2014 (in total 11 sets of minutes) to define the stakeholders within the natural park and the categories they belong to. We further listed the number of times each stakeholder attended these meetings.

\section{Semistructured interviews}

We conducted semistructured interviews $(n=25)$ regarding the participation mechanisms in the natural park with relevant stakeholders. We also asked them to name the people they considered important for natural park management. We selected stakeholders who had an interest in natural park management because they affect or are affected by decisions (Reed et al. 2009). They were selected on the basis of reputation and recommendation from a small pool of initial stakeholders following a snowball sampling strategy. This uses a small pool of initial informants to nominate, through their social networks, other participants who meet the eligibility criteria and who could potentially contribute to a specific study (Newing 2011). To avoid selection bias, we interviewed people from all the sectors present in the natural park, e.g., mayors, park managers, farmers, forest owners, etc. All the interviews were recorded with previous consent.

\section{Survey}

With 65 stakeholders from the natural park, we conducted an online/telephone questionnaire to assess how stakeholders are connected and communicating among themselves. We selected the sample based on: (1) nonparticipant observation; (2) people attending at least three advisory committee meetings, based on reviewed documents; (3) interviewed stakeholders; and (4) stakeholders considered important for natural park management by the interviewees. We obtained a list of 117 people that were supposed to compose the social network of the natural park. To add relevant people or delete people that were no longer linked to the natural park, we sent the list of stakeholders to all the participants $(n=28)$ of the advisory committee meeting held in November 2013 and five key informants selected by ourselves from interviews. They could provided comments on the basis of which we came to a final selection of people connected to the natural park. Finally, 10 people checked the list and we ended up with a final list of 105 people, which was reduced to 98 because of inaccessibility to personal contact details, i.e., email or telephone number. We further established 12 different categories of stakeholders corresponding to sectors present in the natural park, such as local administrations (mayor and councilors of environment), park managers, park employees, representatives of conservationist groups, civic and leisure organizations, workers in the agricultural, scientific, tourism, environmental education, and forestry sectors, and finally, other companies related to the natural park. In the survey, we specifically asked people "With whom do you communicate about issues related to policies and natural resource management in the natural park of Sant Llorenç del Munt?" and "With whom do you have any conflict?" When the list was complete, we asked survey participants for information about sex and relevant stakeholder categories of the persons listed. We also asked stakeholders to introduce their personal data, i.e., name, stakeholder category, and sex. Respondents were informed that their responses would be anonymized because of the sensitivity of the question on conflicts, thereby trying to mitigate the reliability of responses (Marsden 1990). From the 98 people approached, 65 responded (a response rate of $66.32 \%$ ).

\section{Data analysis}

As part of the social network analysis, we used information from the survey to: (1) explore the network of communication of Sant Llorenç del Munt; (2) calculate two individual centrality network measures ("indegree" and "betweenness"); and (3) make clusters of actors that have the same ties to and from the same actors in the network. We assessed the network of communication of Sant Llorenç del Munt using the survey question "With whom do you communicate about issues related to policies and natural resource management in the natural park of Sant Llorenç del Munt?" Data was handled using the software UCInet6-Netdraw for Windows (Borgatti et al. 2010).

We calculated four network-level measures. These measures are informative about the general features of the network, paying attention at the same time to the level of cohesion/fragmentation and the existence of eventual leaders in terms of connections (Borgatti et al. 2010): (1) size, or number of actors in the network; (2) number of components, or the number of connected subgraphs in which all actors are directly or indirectly in contact with each other; (3) density, or the number of links in the network, expressed as a proportion (from 0 to 1 ) of the maximum possible number of links; and (4) indegree network centralization index, or the tendency for a few actors in the network to receive many links or nominations (expressed in percentage).

We also calculated two individual-level centrality measures, both of them widely acknowledged by the literature as reliable indicators of both prestige (indegree; Wasserman and Faust 1994) and brokering capabilities (betweenness; Burt 2003). (1) Indegree, or the number of nominations that a person receives on other people's lists. For example, if four people mentioned one informant when asked to list the name of who he/she communicated with about policy and natural resource management issues in natural park of Sant Llorenç del Munt, then the informant would have an indegree of four. It is a measure that represents more popular/well-connected stakeholders in the network. We used indegree instead of "degree," i.e., the number of links a stakeholder has using data as symmetric, because literature pointed out that indegree is a more robust measure for assessing informal organograms and gives better results under conditions of missing data (Costenbader and Valente 2003). (2) Betweenness, or how many times an actor rests on a short path connecting two others who are themselves disconnected. This 
Fig. 2. Communication network of the natural park of Sant Llorenç del Munt. Note: The size of the nodes indicates the indegree and the shapes indicate the sex (circle for women, a triangle for men, and a square for institutions). In addition, the following colors are used to denote the various categories: red (local administration); green (park managers); yellow (park employees); blue (agricultural sector); orange (scientific sector); purple (civic sector); pale green (conservationist sector); pale blue (leisure sector); pale yellow (environmental education/tourist sector); brown (forestry sector); pink (accommodation and restaurants); pale pink (other enterprises); and white (others).

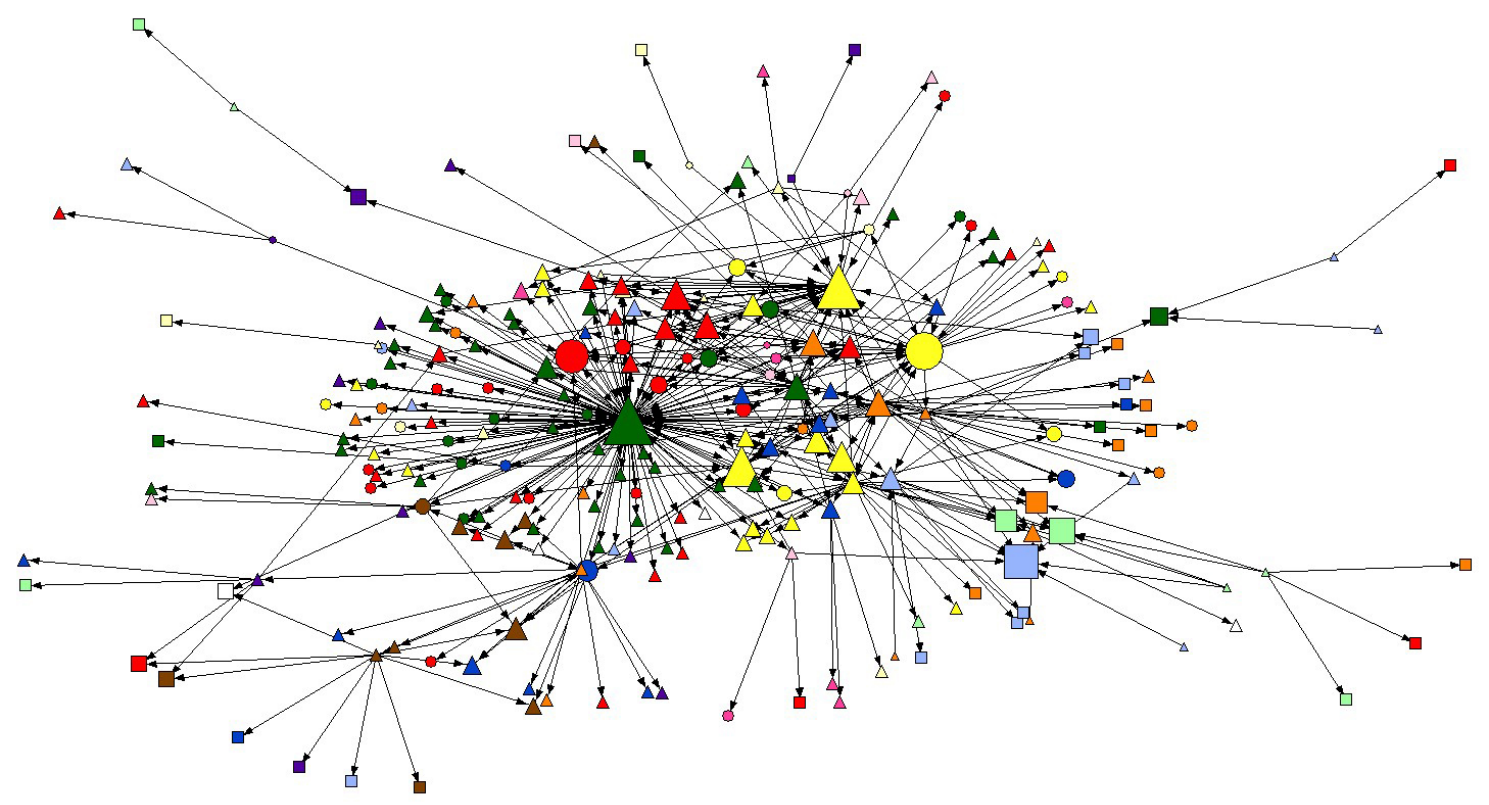

indicates which stakeholders brokered across different stakeholder categories and disconnected segments of the network.

In addition, we measured the level of dyadic reciprocity, i.e., the extent of mutual nominations among stakeholders. We carried out a "core-periphery analysis" (Borgatti and Everett 2000), which has been reported as a typical feature of social networks in general (Mcpherson et al. 2001) and useful for understanding performance in groups (Cummings and Cross 2003). This measure served us to identify which actors belonged to the core and which belonged to the periphery of the network and to verify the relevance of the stakeholders interviewed, thus assuring representation from stakeholders belonging both to the core $(\mathrm{n}=$ $13)$ and the periphery $(n=12)$ of the network.

Next, we ran a single-link hierarchical clustering analysis to assess stakeholders' structural positions (Prell et al. 2008, Prell 2011). This tool groups actors that have the same ties to and from the same actors in the network and thus can be considered to be more or less redundant within the network (Wasserman and Faust 1994). Because there is not a guideline for the number of clusters an analyst can obtain, we split the network into four meaningful clusters based on our previous knowledge of the site.

Finally, the question "With whom do you have any conflict?" served to generate a social network of conflicts within the park to avoid selecting stakeholders who had conflicts in the past to join future participatory processes.
As part of the statistical analysis, we ran Spearman correlations to examine the association between the person's centrality in the communication network and the number of times s/he participated in meetings of the advisory committee between 2008-2014. To test the robustness of the analysis, we undertook a Wilcoxon rank-sum test using both measures of centrality and a binary variable, "AC." This was coded as 1 if the person participated any time in a meeting of the advisory committee and 0 otherwise. Finally, to examine if there were any specific category of stakeholders that hold more centrality, we looked at the mean indegree and betweenness of each category, and based on these descriptive statistics, we ran another Wilcoxon rank-sum test using both measures of centrality and a binary variable named "Park Employees." This was coded as 1 if the person was an employee of the natural park and 0 otherwise. For the statistical analysis we used STATA 12 for Windows.

\section{RESULTS AND DISCUSSION}

\section{The communication network of the natural park}

There exists a network of communication composed of 238 stakeholders and structured in 1 single component (Fig. 2). The network has a very low density (0.008) indicating that there are few ties between stakeholders. It has an indegree centralization index of $11.50 \%$. This is low compared to that of a pure star network with a centralization index of $100 \%$, indicating that the indegree of concentration in the distribution of indegree centralities among the actors is fairly low. This low index shows 
that the network does not have very central (dominant) stakeholders.

The measures discussed indicate that the network of communication of the natural park of Sant Llorenç del Munt is not fragmented because there is only one component, but it is fragile because it is characterized by a low density. A main reason is that some people in the network are connected to only one other person. This is confirmed by the fact that dyadic reciprocity, i.e., the proportion of mutual nominations, is less than $9 \%(0.0829)$, indicating a low level of communication among stakeholders. Connection is very important because it guarantees access of information by many individuals and the building of relations of trust between people (Borgatti and Foster 2003, Rishi 2007). Our results from semistructured interviews pointed out that participatory processes are not working properly because some agreed-upon decisions were finally not implemented. This generated a lack of trust in participatory processes and park managers, which likely contributed to a decrease in communication among certain stakeholders who usually conversed within the space of these processes. For example, one stakeholder said "Participatory processes are not useful, nothing is implemented" and another stated: "They are not operative [...] finally I took distance from park management and participatory processes." This perceived lack of trust between some stakeholders could also increase the reluctance of collaborating with others (Ostrom 1990, 2010). Moreover, it could undermine the positive role that network connections could have in establishing reciprocity (Adger 2003) or in increasing social memory (Bodin et al. 2006). With regard to the low degree of centralization of the park's social network, literature has characterized both advantages and disadvantages. In the case of the former, it may increase the exchange of different types of knowledge within the network engaging people into a continuous learning process whereby management of the natural park can be updated and adapted (Holling 1978, Bodin et al. 2006, Prell et al. 2007). Our results showed a high diversity of stakeholders and organizations within the natural park, which may sow the necessary conditions for processes of cooperation and learning in decision making. As several interviewees highlighted, the existence of multiple stakeholders involved in the natural park permits the integration of different perspectives necessary for a comprehensive management of the protected area. However under current conditions of mistrust, learning and adaptive capacities of the network might be weakened (Bodin et al. 2006). In terms of disadvantages, a low degree of centralization can hamper adaptive capacity to changing conditions because it may diminish coordination ability to cope with problems (Leavitt 1951, Prell et al. 2007). Nevertheless, some actors, notably the park director and several park employees, hold a high indegree (Fig. 2) and are also the ones who hold major responsibilities for park management. This could overcome the lack of coordination assumed in a low centralized network.

The results suggest that an informal network of communication exists and holds the potential to deal with the management of the natural park. However, it is probably less effective than it could be because of a lack of trust in the effectiveness of participatory bodies, such as the advisory committee, by some stakeholders. Several studies indicate that lack of trust is a major reason for ineffective natural resource management. This has been illustrated for such different issues as weed management (Graham 2014), farm management (Hernández-Jover et al. 2012), wild animal management (Davies and White 2012), and management of marine protected areas (Ho et al. 2014). A common thread in these studies is the necessity to generate or rebuild trust between stakeholders and formal organizations.

\section{Do participatory bodies represent the social network of the natural park?}

Results from the Spearman correlations (Table 1) indicate that stakeholders who hold more indegree and betweenness are also the ones who participate the most in advisory committee meetings (see Fig. 3 for a graphical representation). However, the correlation was only statistically significant for betweenness ( $p=$ $0.000)$ and not for indegree $(p=0.108)$. Results of Wilcoxon ranksum test showed the same pattern (Table 2). The category that held more centrality was the park employees, but the association was only significant for indegree $(p=0.000)$ and not for betweenness ( $p=0.672$; Table 3 ). Regarding these results, we can say that central stakeholders of the communication network are represented in participatory bodies. However, the abovementioned lack of trust can have negative effects on the social network. Thus, it is interesting to discuss the role these participatory bodies can have in enhancing communication among stakeholders.

Table 1. Spearman correlations between individual centrality and assistance to advisory committee meetings $(n=198)$.

\begin{tabular}{lc}
\hline \hline & Assistance to advisory committee \\
\hline Indegree & 0.115 \\
Betweenness & $0.369^{* * *}$ \\
\hline$* * *$ Significant at $\mathrm{p} \leq 1 \%$. & \\
\hline
\end{tabular}

Table 2. Wilcoxon rank-sum text between individual centrality and assistance to advisory committee meetings $(\mathrm{n}=198)$.

\begin{tabular}{|c|c|c|c|c|c|c|c|c|}
\hline & \multicolumn{4}{|c|}{ Indegree } & \multicolumn{4}{|c|}{ Betweenness } \\
\hline & Mean & SD & Min & $\operatorname{Max}$ & Mean & SD & Min & Max \\
\hline Assistance & 2.70 & 5.03 & 0 & 29 & $279.98 * * *$ & 1139.85 & 0 & 8844.74 \\
\hline $\begin{array}{l}\text { No } \\
\text { assistance }\end{array}$ & 1.55 & 1.65 & 0 & 16 & 29.53 & 138.27 & 0 & 1008.66 \\
\hline
\end{tabular}

Table 3. Wilcoxon rank-sum text between individual centrality and working at the natural park $(\mathrm{n}=238)$.

\begin{tabular}{|c|c|c|c|c|c|c|c|c|}
\hline & \multicolumn{4}{|c|}{ Indegree } & \multicolumn{4}{|c|}{ Betweenness } \\
\hline & Mean & $\mathrm{SD}$ & Min & $\operatorname{Max}$ & Mean & SD & Min & $\operatorname{Max}$ \\
\hline $\begin{array}{l}\text { Park } \\
\text { employees }\end{array}$ & $4.2 * * *$ & 6.10 & 1 & 28 & 227.14 & 565.84 & 0 & 2112.94 \\
\hline $\begin{array}{l}\text { No park } \\
\text { employees }\end{array}$ & 1.60 & 2.24 & 0 & 29 & 77.22 & 616.76 & 0 & 8844.74 \\
\hline
\end{tabular}


Fig. 3. Communication network of the natural park and assistance to the advisory committee meetings. Note: The size of the nodes indicates the betweenness and the shapes indicate the assistance to the advisory committee meetings (circle for assistance, diamond for no assistance, rounded-square for missing data, i.e., institutions). In addition, the following colors are used to denote the various categories: red (local administration); green (park managers); yellow (park employees); blue (agricultural sector); orange (scientific sector); purple (civic sector); pale green (conservationist sector); pale blue (leisure sector); pale yellow (environmental education/tourist sector); brown (forestry sector); pink (accommodation and restaurants); pale pink (other enterprises); and white (others).

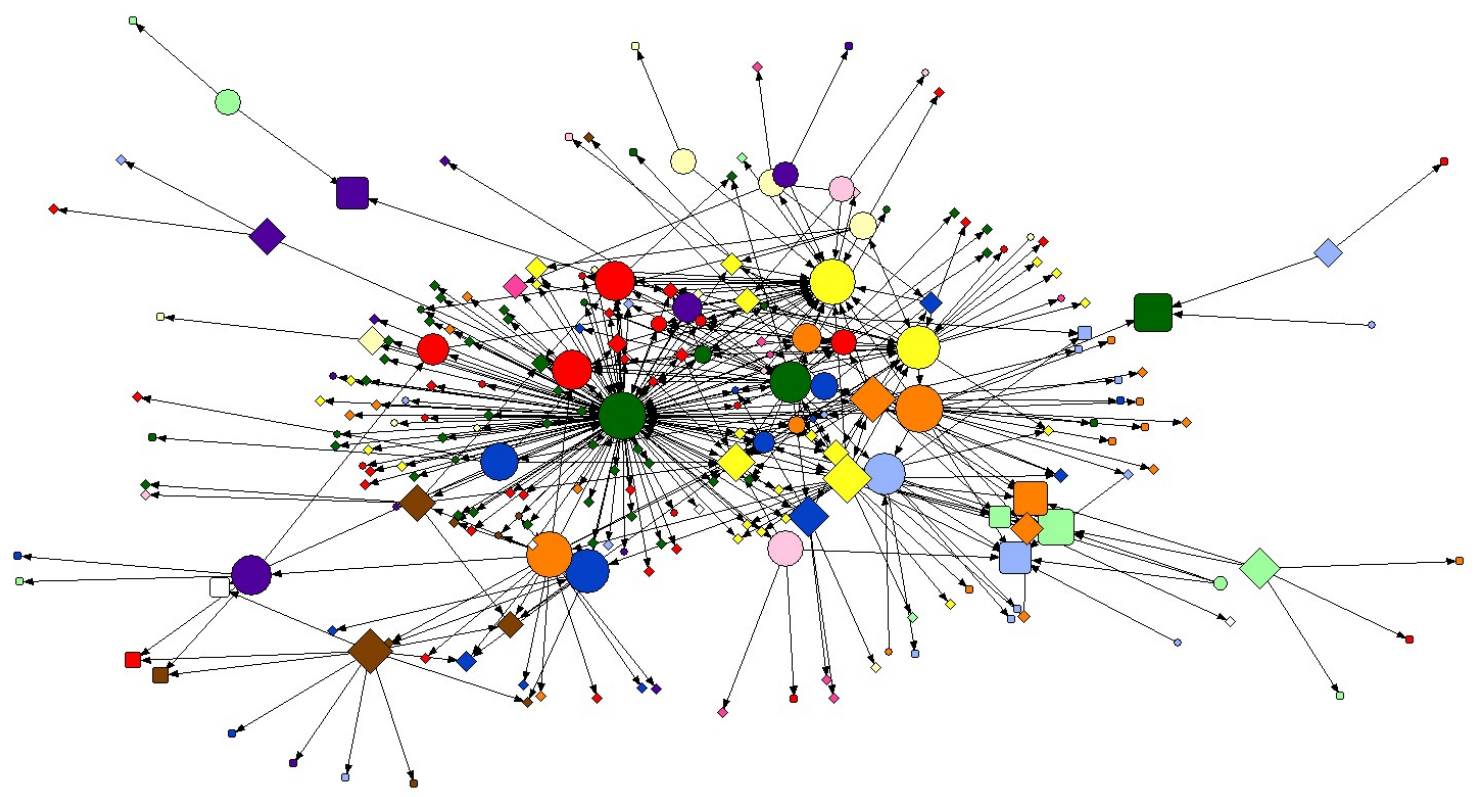

At first glance, we could say that the advisory committee works as a positive feedback loop (Beilin et al. 2013) reinforcing the existence of the social network of communication in the natural park. One of the stakeholders interviewed put it this way: "The advisory committee is a place for exchanging information and knowledge and to meet with each other." Beilin et al. (2013) highlight that the attendance to social events underpins community engagement in community-based, natural resource management through the strengthening of social networks.

However, if lack of trust and frustration (Hoppe 2010) are taking place, then a negative feedback loop may be created, which results in some stakeholders dropping out of the network or being placed into the periphery, as a consequence of disempowerment or disengagement with the group's interests (Beilin et al. 2013). One of the farmers interviewed expressed this with the following words: "The farmers are not any longer going to the meetings as these do not represent our interests and do not work well. We are the land managers, the land custodians and people do not recognize it."' The exclusion of some stakeholders, e.g., agricultural producers, from the advisory committee meetings could represent a loss of a central position in the communication network. This might result in losing valuable management land knowledge for the entire network.

Our overall results reveal that the three aspects, i.e., communication, trust, and participation, are interrelated. The process of building trust (mistrust) through communication and participation reinforces (weakens) the communication network and effectiveness of participatory bodies. At the same time, participation can reinforce or weaken the communication network and vice versa.

The centrality of park employees in the communication network might be caused by the necessity to maintain internal connectivity centered on certain members in official roles to keep the stakeholders informed about park issues (Beilin et al. 2013). We argue that this form of connectivity could be effective if trust and power work in synergy, obtaining positive effects such as sharing information, providing support, and increasing cooperation (Vollan 2008, Graham 2014). However, if legitimate power, i.e., a person's perception that a social agent has a legitimate right to prescribe behavior for him (French and Raven 1959), acts as substitute of trust, the outcomes can have ramifications throughout social networks with negative consequences for the achievement of collective action (Graham 2014).

\section{Selection of stakeholders for assessing the adequate governance structure of the natural park}

As mentioned above, results from nonparticipant observation and semistructured interviews showed a general disappointment with participatory bodies. We used the outputs of social network analysis to select stakeholders because our results also proved that there exists an informal communication network in the natural park and that it is, at least partially, interlinked with formal 
Table 4. Stakeholders selected for future participatory processes.

\begin{tabular}{|c|c|c|c|c|c|}
\hline Category & Indegree & Betweenness & Core/Periphery & Cluster & Person \\
\hline Local administration & 7 & 878.79 & Core & 4 & Mayor of a municipality \\
\hline Park managers & 29 & 8844.74 & Core & 1 & Park director \\
\hline Park employees & 28 & 2112.94 & Core & 4 & Park technician \\
\hline Agricultural sector & 4 & 537.04 & Periphery & 3 & Farmer \\
\hline Scientific sector & 5 & 158.523 & Core & 3 & $\begin{array}{l}\text { Veterinarian of Universitat } \\
\text { Autònoma de Barcelona }\end{array}$ \\
\hline Civic sector & 1 & 107.500 & Periphery & 2 & Local activist \\
\hline Conservationist sector & 5 & 0 & Periphery & 2 & $\begin{array}{l}\text { Member of a conservationist } \\
\text { organization }\end{array}$ \\
\hline Leisure sector & 4 & 241.375 & Periphery & 3 & Member of a hiking group \\
\hline $\begin{array}{l}\text { Environmental } \\
\text { education/Tourist sector }\end{array}$ & 1 & 80.37 & Periphery & 1 & $\begin{array}{l}\text { Member of a cooperative working } \\
\text { on environmental education }\end{array}$ \\
\hline Forestry sector & 4 & 392.00 & Periphery & 2 & $\begin{array}{l}\text { President of a forestry defense } \\
\text { association }\end{array}$ \\
\hline $\begin{array}{l}\text { Accommodation and } \\
\text { restaurants sector }\end{array}$ & 1 & 114.46 & Periphery & 1 & Manager of a restaurant \\
\hline Other enterprises & 1 & 114.29 & Periphery & 3 & Environmental restoration manager \\
\hline
\end{tabular}

participatory institutions. Based on measures of indegree and betweenness centrality, network of conflicts between stakeholders, core-periphery and hierarchical clustering analysis, and category of stakeholder, we selected 12 participants for future participatory processes (Table 4). These participants represent the various categories of stakeholders identified within the natural park. Prell et al. (2011) reflect on the importance of diversity when considering a wide representation of stakeholders. The person selected from each category was the one who obtained both a higher indegree and betweenness centrality. High indegree centrality guarantees that these actors can motivate the network and rapidly diffuse information through it, and high betweenness centrality assures that actors link disconnected segments of the network because they have a more holistic view of the entire network and have the capacity to mobilize and diffuse information to the larger network (Prell et al. 2008, 2011). Notwithstanding, as the literature notes (Prell 2011), it is possible that focusing on more central actors does not lead to the best selection of stakeholders. For this reason, we made sure that our selection included people from the core and the periphery of the network and that the four clusters obtained in the hierarchical clustering analysis were represented in our selection. By avoiding homophily, i.e., a situation in which similar actors are attracted to one another and thus choose to interact with each other, we made sure to avoid gathering redundant information (Prell et al. 2010) and to guarantee diversity based on social networks, i.e., diverse positions within a wider network structure (Prell et al. 2011). Because having stakeholders from different backgrounds could lead to conflicts and difficulties in transferring tacit and complex information (Prell et al. 2011), our stakeholder selection also avoided bringing together people with some degree of conflict to achieve a maximally productive assessment of the governance structure of the natural park.

\section{CONCLUSIONS}

Results from our study suggest that the communication network of Sant Llorenç is fragile because of the few ties between stakeholders, which reflect a lack of trust and little knowledge exchange. Our research also suggests that central stakeholders of the communication network are represented in participatory bodies of the natural park. We argue that social network analysis is an appropriate tool to identify central stakeholders of different categories to support participatory processes. In light of these findings, we consider it important to improve the functioning of participatory bodies and to initiate participatory processes to generate or rebuild trust, share information, provide support, and increase cooperation between stakeholders. Further research could address the question of which network structures are most suitable for local participation in governance (Barabási 2009, Newman 2003) to advance the field of social network analysis and natural resource management.

Because effective governance of protected areas has been deemed a priority in developed and developing countries, the implications of our findings are not limited to the natural park of Sant Llorenç del Munt. As Ernstson (2011) noted, we argue that transformative change in natural resource management is critical for the maintenance of social-ecological systems. We suggest that social network analysis, beyond being a supportive tool for stakeholder analysis (Prell et al. 2008), can help in the aforementioned transformation supporting protected areas' policies and governance.

Responses to this article can be read online at: http://www.ecologyandsociety.org/issues/responses. $\mathrm{php} / 7989$

\section{Acknowledgments:}

The research was supported by the project CONNECT - Linking biodiversity conservation and ecosystem services, which is part of ERA-NET BiodivERsA 2 (http://www.biodiversa.org). We received national funding from Programas Internacionales of the Spanish Ministry of Science and Innovation (ref.PRIPIMBDV-2011-1053). We thank stakeholders for their kind and selfless participation in the study. Two anonymous reviewers and 
the journal editor also provided very useful comments to improve the article. Thanks also go to Laia Echániz-Pou for elaboration of the map of the study area and to Daniel Corbacho-Monné for help with the figures and tables.

\section{LITERATURE CITED}

Adger, W. N. 2003. Social capital, collective action, and adaptation to climate change. Economic Geography 79:387-404. http://dx.doi.org/10.1111/j.1944-8287.2003.tb00220.x

Aguilar Cestero, R. 2012. Memòries d'una feixa. La urbanització d'un poble pagès de la Regió de Barcelona (Matadepera, 1931-1983). República de Paper. Ecos, Barcelona, Spain.

Barabási, A.-L. 2009. Scale-free networks: a decade and beyond. Science 325(5939):412-413. http://dx.doi.org/10.1126/science.1173299

Beilin, R., N. T. Reichelt, B. J. King, A. Long, and S. Cam. 2013. Transition landscapes and social networks: examining on-ground community resilience and its implications for policy settings in multiscalar systems. Ecology and Society 18(2):30. http://dx.doi. org/10.5751/es-05360-180230

Bessette, G. 2004. Involving the community. A guide to participatory development communication. International Development Research Centre, Ottawa, Ontario, Canada. [online] URL: http://www.idrc. ca/EN/Resources/Publications/openebooks/066-7/index.html

Blackstock, K. L., and C. Richards. 2007. Evaluating stakeholder involvement in river basin planning: a Scottish case study. Water Policy 9:493-512. http://dx.doi.org/10.2166/wp.2007.018

Bodin, Ö., B. I. Crona, and H. Ernstson. 2006. Social networks in natural resource management: what is there to learn from a structural perspective? Ecology and Society 11(2):2. http://www. ecologyandsociety.org/vol11/iss2/resp2 http://dx.doi.org/10.1017/ $\underline{\mathrm{cbo} 9780511894985}$

Bodin, Ö., and B. I. Crona. 2009. The role of social networks in natural resource governance: what relational patterns make a difference? Global Environmental Change 19:366-374.

Borgatti, S. P., and M. G. Everett. 2000. Models of core/periphery structures. Social Networks 21(4):311-410. http://dx.doi. org/10.1016/S0378-8733(99)00019-2

Borgatti, S. P., M. G. Everett, and L. C. Freeman. 2010, 2002. Ucinet for Windows: software for social network analysis. Analytic Technologies, Harvard, Massachusetts, USA.

Borgatti, S. P., and P. C. Foster. 2003. The network paradigm in organizational research: a review and typology. Journal of Management 29(6):991-1013.

Borrini-Feyerabend, G., N. Dudley, T. Jaeger, B. Lassen, N. Pathak Broome, A. Phillips, and T. Sandwith. 2013. Governance of protected areas: from understanding to action. Best practice protected area guidelines. Series no. 20. IUCN, Gland, Switzerland. [online] URL: https://www.iucn.org/about/work/ programmes/gpap_home/gpap_capacity2/gpap_bpg/?13678/Governanceof-Protected-Areas-From-understanding-to-action

Burroughs, R. 1999. When stakeholders choose: process, knowledge, and motivation in water quality decisions. Society and Natural Resources 12:797-809. http://dx.doi.org/10.1080/089419$\underline{299279326}$
Burt, R. S. 2004. Structural holes and good ideas. American Journal of Sociology 110(2):349-399. http://dx.doi.org/10.1086/421787

Convention on Biological Diversity (CBD). 1992. Convention on biological diversity: text and annexes. Convention on Biological Diversity Interim Secretariat, Geneva, Switzerland.

Costenbader, E., and T. W. Valente. 2003. The stability of centrality measures when networks are sampled. Social Networks 25(4):283-307. http://dx.doi.org/10.1016/s0378-8733(03)00012-1

Cummings, J. N., and R. Cross. 2003. Structural properties of work groups and their consequences for performance. Social Networks 25 (3):197-210. http://dx.doi.org/10.1016/s0378-8733 (02)00049-7

Davies, A. L, and R. M. White. 2012. Collaboration in natural resource governance: reconciling stakeholder expectations in deer management in Scotland. Journal of Environmental Management 112:160-169. http://dx.doi.org/10.1016/j.jenvman.2012.07.032

Diputació de Barcelona. 1997. Modificació del Pla Especial de Protecció del Medi Físic i del Paisatge de l'Espai Natural de Sant Llorenç del Munt i l'Obac. Text Normatiu Espai Natural Sant Llorenç del Munt i l'Obac. Diputació de Barcelona, Barcelona, Spain.

Diputació de Barcelona. 2012. Memòria 2011 del Parc Natural de Sant Llorenç del Munt i l'Obac. Xarxa de Parcs Naturals, Barcelona, Spain.

Dudley, N. 2008. Guidelines for applying protected area management categories. IUCN, Gland, Switzerland.

Ernstson, H. 2011. Transformative collective action: a network approach to transformative change in ecosystem based management. Pages 255-287 in Ö. Bodin and C. Prell, editors. Social networks and natural resource management: uncovering the social fabric of environmental governance. Cambridge University Press, Cambridge, UK. http://dx.doi.org/10.1017/cbo9780511894985.012

European Union. 2011. The EU biodiversity strategy to 2020. Publications Office of the European Union, Luxembourg City, Luxembourg.

Freeman, R. E. 1984. Strategic management. A stakeholder approach. Basic Books, New York, New York, USA http://dx.doi. org/10.1017/cbo9781139192675

Fiorino, D. J. 1990. Citizen participation and environmental risk: a survey of institutional mechanisms. Science, Technology, and Human Values 15:226-243. http://dx.doi.org/10.1177/016224399001500204

Fischer, F. 1993. Citizen participation and the democratization of policy expertise: from theoretical inquiry to practical cases. Policy Sciences 26:165-187. http://dx.doi.org/10.1007/BF00999715

French, J. R. P, and B. H. Raven. 1959. The bases of social power. Pages 150-167 in D. Cartwright, editor. Studies in social power. Institute of Social Research, University of Michigan, Ann Arbor, Michigan, USA.

Frooman, J. 1999. Stakeholder influence strategies. Academy of Management Review 24:191-205.

Graham, S. 2014. A new perspective on the trust power nexus from rural Australia. Journal of Rural Studies 36:87-98. http://dx. doi.org/10.1016/j.jrurstud.2014.06.010 
Grimble, R., and K. Wellard. 1997. Stakeholder methodologies in natural resource management: a review of concepts, contexts, experiences and opportunities. Agricultural Systems 55:173-193. http://dx.doi.org/10.1016/S0308-521X(97)00006-1

Hernández-Jover, M., J. Gilmour, N. Schembri, T. Sysak, P. K. Holyoake, R. Beilin, and J.-A. L. M. L. Toribio. 2012. Use of stakeholder analysis to inform risk communication and extension strategies for improved biosecurity amongst small-scale pig producers. Preventive Veterinary Medicine 104:258-270. http://dx. doi.org/10.1016/j.prevetmed.2011.12.006

Ho, T. V. T., S. Woodley, A. Cottrell, and P. Valentine. 2014. A multilevel analytical framework for more effective governance in human-natural systems: a case study of marine protected areas in Vietnam. Ocean and Coastal Management 90:11-19. http://dx. doi.org/10.1016/j.ocecoaman.2013.12.015

Holling, C. S. 1978. Adaptive environmental assessment and management. John Wiley, New York, New York, USA.

Hoppe, R. 2010. Institutional constraints and practical problems in deliberative and participatory policy making. Policy and Politics 39:163-186. http://dx.doi.org/10.1332/030557310X519650

Hutton, J., W. M. Adams, and J. C. Murombedzi. 2005. Back to the barriers? Changing narratives in biodiversity conservation. Forum for Development Studies 2:341-370. http://dx.doi. org/10.1080/08039410.2005.9666319

International Union for Conservation of Nature (IUCN). 1994. Guidelines for applying protected area management categories. IUCN, Gland, Switzerland.

Leavitt, H. 1951. Some effects of certain communication patterns on group performance. Journal of Abnormal and Social Psychology 46:38-50. http://dx.doi.org/10.1037/h0057189

Marsden, P. V. 1990. Network data and measurement. Annual Review of Sociology 16:435-463. http://dx.doi.org/10.1146/ annurev.so.16.080190.002251

McNeely, J., editor. 1992. Parks for life: report of the IVth world congress on national parks and protected areas. IUCN, Gland, Switzerland.

Mcpherson, M., L. Smith-lovin, and J. M. Cook. 2001. Birds of a feather: homophily in social networks. Annual Review of Sociology 27:415-444. http://dx.doi.org/10.1146/annurev.soc.27.1.415

Newing, H. 2011. Conducting research in conservation: social science methods and practice. Routledge, London, UK.

Newman, M. E. J. 2003. The structure and function of complex networks. SIAM Review 45(2):167-256. http://dx.doi.org/10.1137/ $\underline{\mathrm{s} 003614450342480}$

Ostrom, E. 1990. Governing the commons: the evolution of institutions for collective action. Cambridge University Press, Cambridge, UK.

Ostrom, E. 2010. Analyzing collective action. Agricultural Economics 41:155-166. http://dx.doi.org/10.1111/j.1574-0862.2010.00497. $\underline{\mathrm{X}}$

Otero Armengol, I. 2010. The rural-urban socioecological transformation of Mediterranean mountain areas under global change. Local studies in Olzinelles and Matadepera (Barcelona Metropolitan Region). Dissertation. Universitat Autònoma de Barcelona, Barcelona, Spain.

Prell, C. 2011. Some basic structural characteristics of networks. Pages 29-43 in Ö. Bodin and C. Prell, editors. Social networks and natural resource management: uncovering the social fabric of environmental governance. Cambridge University Press, Cambridge, UK. http://dx.doi.org/10.1017/cbo9780511894985.003

Prell, C., K. Hubacek, C. Quinn, and M. Reed. 2008. 'Who's in the network?' When stakeholders influence data analysis. Systemic Practice and Action Research 21:443-458. http://dx.doi. org/10.1007/s11213-008-9105-9

Prell, C., K. Hubacek, and M. Reed. 2007. Stakeholder analysis and social network analysis in natural resource management. SRI Papers. University of Leeds, Leeds, UK.

Prell, C., K. Hubacek, and M. Reed. 2009. Stakeholder analysis and social network analysis in natural resource management. Society and Natural Resources 22:501-518. http://dx.doi. org/10.1080/08941920802199202

Prell, C., M. Reed, L. Racin, and K. Hubacek. 2010. Competing structure, competing views: the role of formal and informal social structures in shaping stakeholder perceptions. Ecology and Society 15(4):34. [online] URL: http://www.ecologyandsociety. org/vol15/iss4/art34/

Prell, C., M. Reed, and K. Hubacek. 2011. Social network analysis for stakeholder selection and the links to social learning and adaptive co-management. Pages 95-118 in Ö. Bodin and C. Prell, editors. Social networks and natural resource management: uncovering the social fabric of environmental governance. Cambridge University Press, Cambridge, UK. http://dx.doi. org/10.1017/cbo9780511894985.006

Reed, M. S. 2008. Stakeholder participation for environmental management: a literature review. Biological Conservation 141:2417-2431. http://dx.doi.org/10.1016/j.biocon.2008.07.014

Reed, M. S., A. Graves, N. Dandy, H. Posthumus, K. Hubacek, J. Morris, C. Prell, C. H. Quinn, and L. C. Stringer. 2009. Who's in and why? A typology of stakeholder analysis methods for natural resource management. Journal of Environmental Management 90:1933-1949. http://dx.doi.org/10.1016/j. jenvman.2009.01.001

Rishi, P. 2007. Joint forest management in India: an attitudinal analysis of stakeholders. Resources, Conservation and Recycling 51:345-354. http://dx.doi.org/10.1016/j.resconrec.2006.10.009

Ruiz-Mallén, I., A. De la Peña, M. E. Méndez-Lopez, and L. Porter-Bolland. 2013. Local participation in community conservation: methodological contributions. Pages 117-133 in L. Porter-Bolland, I. Ruiz-Mallén, C. Camacho-Benavides, and S. R. McCandless, editors. Community action for conservation: Mexican experiences. Springer, Berlin, Germany. http://dx.doi. org/10.1007/978-1-4614-7956-7 8

Vollan, B., 2008. Socio-ecological explanations for crowding-out effects from economic field experiments in southern Africa. Ecological Economics 67:560-573. http://dx.doi.org/10.1016/j. ecolecon.2008.01.015 
Wasserman, S., and F. Faust. 1994. Social network analysis: methods and applications. Cambridge University Press, Cambridge, UK. http://dx.doi.org/10.1017/cbo9780511815478

Wesselink, A., J. Paavola, O. Fritsch, and O. Renn. 2011. Rationales for public participation in environmental policy and governance: practitioners' perspectives. Environment and Planning A 43:2688-2704. http://dx.doi.org/10.1068/a44161 